\title{
The expression of HoxB5 and SPC in neonatal rat lung after exposure to fluoxetine
}

This article was published in the following Dove Press journal:

Drug Design, Development and Therapy

2 November 2016

Number of times this article has been viewed

\author{
Razieh Taghizadeh' \\ Zahra Taghipour ${ }^{2}$ \\ Akbar Karimi' \\ Ali Shamsizadeh ${ }^{3}$ \\ Mohammad Mohsen \\ Taghavi $^{2}$ \\ Mahdi Shariati² \\ Ahmad Shabanizadeh ${ }^{2}$ \\ Hamid Reza Jafari Naveh ${ }^{2}$ \\ Reza Bidaki ${ }^{4}$ \\ Fariba Aminzadeh ${ }^{5}$ \\ 'Department of Biology, Payame Noor \\ University, Isfahan, Iran; ${ }^{2}$ Department \\ of Anatomy, Rafsanjan University of \\ Medical Sciences, Rafsanjan, Iran; \\ ${ }^{3}$ Department of Physiology, Rafsanjan \\ University of Medical Sciences, \\ Rafsanjan, Iran; ${ }^{4}$ Shahid Sadoughi \\ University of Medical Sciences, Yazd, \\ Iran; ${ }^{5}$ Rafsanjan University of Medical \\ Sciences, Rafsanjan, Iran
}

Correspondence: Zahra Taghipour Department of Anatomy, Rafsanjan University of Medical Sciences,

Rafsanjan, Iran

Tel +98343 I3| 5064

Email taghipourz@yahoo.com
Objective: Approximately $10 \%$ of pregnant women suffer from pregnancy-associated depression. Fluoxetine, as a selective serotonin reuptake inhibitor, is being employed as a therapy for depressive disorders. The present study aimed to determine the effects of fluoxetine on neonatal lung development.

Methods: Thirty pregnant Wistar rats (weighing 200-250 g) were treated daily with $7 \mathrm{mg} / \mathrm{kg}$ fluoxetine from gestation day 0 to gestation day 21, via gavage. The control group received a similar volume of distilled water only. Following delivery, the newborns and their lungs were immediately weighed in both of the groups. The right lung was fixed for histological assessments while the left lung was used for evaluation of the expression of SPC and HoxB5 by the real-time polymerase chain reaction method.

Results: Results have indicated that even though the body weight and the number of neonatal rats in both groups were the same, the lung weight of neonates exposed to fluoxetine was significantly different compared to the control group $(P<0.05)$. Expression of both genes was increased, nonetheless, only elevation of HoxB5 was significant $(P<0.05)$. Histological studies demonstrated that lung tissue in the fluoxetine treatment group morphologically appears to be similar to the pseudoglandular phase, whereas the control group lungs experienced more development.

Conclusion: According to the upregulated expression of HoxB5 concerning histological findings, results of the present study showed that fluoxetine can influence lung growth and may in turn lead to delay in lung development. So establishment of studies to identify the effects of antidepressant drugs during pregnancy is deserved.

Keywords: fluoxetine, rat, lung, HoxB5, SPC

\section{Introduction}

Approximately 350 million people are suffering from depression as a frequent disorder worldwide. This disorder affects several aspects of life, including an individual's relationship, capacity to work, and financial status and can lead to self-harm and even suicide. The prevalence of depression in females is two-fold higher than in males. Women are at increased risk of depression during periods of hormone changes in various states such as during maturity, pregnancy, and menopause. ${ }^{1}$

Evidences revealed that depression is a risk factor for both preterm birth and low birth weight, and hence it is important to cure gestational depression. ${ }^{2}$ A number of studies have suggested that selective serotonin reuptake inhibitors (SSRIs) are the first-line treatment drugs for depression therapy. ${ }^{3}$ Fluoxetine is an SSRI medication that is known as an important antidepressant drug for gestational depression which has been used during the last 2 decades ${ }^{4}$ Fluoxetine is able to cross the placenta and therefore induces some side effects on fetal development, including risk of persistent 
pulmonary hypertension of the newborn (PPHN). PPHN has been reported to occur in one to two per 1,000 liveborn infants and is associated with some important diseases and mortalities in newborns. Epidemiological studies have reported positive statistical correlation between PPHN and fluoxetine consumption during pregnancy. ${ }^{5}$

Several studies have demonstrated that fluoxetine affects both the level of pulmonary hypertension ${ }^{6,7}$ and alters the thickness of the pulmonary arterial wall. ${ }^{8,9}$ Although many studies have examined the effects of fluoxetine on exposed neonates, there exists no studies to evaluate the evolutionary changes in bronchial tree and alveolar cells. Concerning the most recent studies, it is essential to evaluate the effect of fluoxetine on lung tissue and evolution of the bronchial tree. The expression of the HoxB5 gene is reported to commence at the earliest stages of lung development, peak at the end of the pseudoglandular stage, and finally diminish when branching morphogenesis is quite completed. After the birth, HoxB5 is expressed by type I, while SPC genes are expressed in type II alveolar epithelial cells. ${ }^{10-13}$ The SPC gene provides a direction for the building of one of the four surfactant proteins and mutations in the SPC gene that will lead to chronic interstitial lung diseases in both infants and adults. ${ }^{14,15}$ Therefore, the present study aimed to evaluate the effects of fluoxetine on the processes of lung development via measuring the expression of SPC and HoxB5 levels in neonatal rat lung.

\section{Materials and methods \\ Animals}

All animal protocols were carried out in accordance with the guidelines for the care and use of laboratory animals at the Rafsanjan University of Medical Sciences and rules and regulations of the European Communities Council Directive, November 24, 1986 (86/609/EEC). Thirty female Wistar rats weighing 200-250 g were kept and used under controlled conditions at $22^{\circ} \mathrm{C} \pm 2{ }^{\circ} \mathrm{C}$ and a constant 12 hours light/12 hours dark cycle. Rats had free access to food and water. Every three female rats were placed in contact with an adult male rat for mating. After 24 hours, vaginal smears were evaluated in female rats. The day of sperm detection in the vaginal smear was considered day 0 of pregnancy (gestation day 0$).{ }^{16}$ Then, the female rats were randomly separated into treatment and control groups. The treatment group was initially treated by gastric gavage with fluoxetine at $10 \mathrm{mg} / \mathrm{kg}$ once per day ${ }^{17}$ from days 0 to 21 of gestation. Because rats could not tolerate this dose, the dose was reduced and the maximum dose for this study was $7 \mathrm{mg} / \mathrm{kg}$. The control rats received a similar volume of distilled water. Immediately after delivery, the weights of pups were recorded and lungs were removed surgically. Then, lung weights were recorded, next, the left lung was fixed in TRizol reagent for real-time polymerase chain reaction (PCR) and the right lung was fixed in formalin for histological analysis.

\section{Real-time PCR}

Total RNA was extracted from the lung tissue using TRizol reagent according to the manufacturer's protocol. Extracted RNA was purified by isolation kits and used as a template for reverse transcription in cDNA synthesis. The cDNA synthesis kit was used for cDNA synthesis using both oligo (dT) and random hexamer primers. Real-time PCR was performed on all lung samples. This reaction was undertaken for HoxB5, SPC, and $\beta$-actin (housekeeping gene) genes in triplicate. Designed primers for each gene were controlled thermodynamically, then, they were evaluated in the BLAST database to verify the absence of nonspecific binding to other regions of the genome. The sequences of primers used are described in Table 1.

Real-time PCR was performed using $10 \mu \mathrm{L}$ of SYBR green master mix, $3 \mu \mathrm{L}$ of cDNA, $5 \mu \mathrm{L}$ of distilled water, $2 \mu \mathrm{L}$ of each primer, either forward or reverse primer. The following program was programmed on a Bio-Rad CFX96 system (Bio-Rad Laboratories Inc., Hercules, CA, USA) for PCR amplification. There was one cycle of $95^{\circ} \mathrm{C}$ for 10 minutes to activate the hot start Taq polymerase enzyme and DNA denaturation, 40 cycles of $95^{\circ} \mathrm{C}$ for 15 seconds, and 40 cycles of $58^{\circ} \mathrm{C}$ for 1 minute. Drawing of separation curve was performed using the following cycle: $95^{\circ} \mathrm{C}$ for 15 seconds, $60^{\circ} \mathrm{C}$ for 30 seconds, and $95^{\circ} \mathrm{C}$ for 15 seconds, and the temperature was reduced from $95^{\circ} \mathrm{C}$ to $60^{\circ} \mathrm{C}$ at $0.03^{\circ} \mathrm{C}$ per second in this step. The relative quantification

Table I The sequence of primers used for real-time polymerase chain reaction in the study

\begin{tabular}{lll}
\hline Gene & Forward primer & Reverse primer \\
\hline SPC & CCTTGAGATGAGCATCGGAG & AGAAGGTAGCGATGGTGTCT \\
HoxB5 & CTCCTTCTCGGGGCGTTATC & CGGTTGACGCTGAGATCCAT \\
$\beta$-Actin & GATATCGCTGCGCTCGTCG & CCCATACCCACCATCACACC \\
\hline
\end{tabular}


of PCR products was determined using the $2^{-\Delta \mathrm{Ct}}$ formula. ${ }^{18}$ The melting curves, quantitative analyses, and dissociation stages of the data were performed using the CFX manager software.

\section{Histological and morphological analyses}

The right lung samples which had already been fixed in formalin were embedded in paraffin, then the tissues were sectioned at $8 \mu \mathrm{m}$ and were stained with hematoxylin and eosin. The samples were studied under a light microscope.

\section{Results}

\section{Body and lung weight}

Our results showed that the mean body weight of newborns of the fluoxetine-exposed group (5.75 $\pm 0.05 \mathrm{~g}$ ) was not significantly reduced compared to the control group $(5.90 \pm 0.09 \mathrm{~g})$ (Figure 1). We observed that fluoxetine-exposed newborns' lung weight was significantly reduced compared to control newborns' lung weight $(0.11 \pm 0.006 \mathrm{~g}$ and $0.14 \pm 0.004 \mathrm{~g}$, respectively) $(P=0.001)$ (Figure 2$)$.

\section{Number of newborns}

There were no statistically significant differences between the average number of live-born infants in the fluoxetine treatment group and the control group (average: $7 \pm 1.5$ and $8.25 \pm 1.6$, respectively) (Figure 3).

\section{HoxB5 and SPC gene expression}

The mRNA of HoxB 5 was expressed in rat lungs. When a comparison was made between the fluoxetine treatment group and the control group, a significant difference was observed. The expression of the HoxB5 gene in the fluoxetine treatment

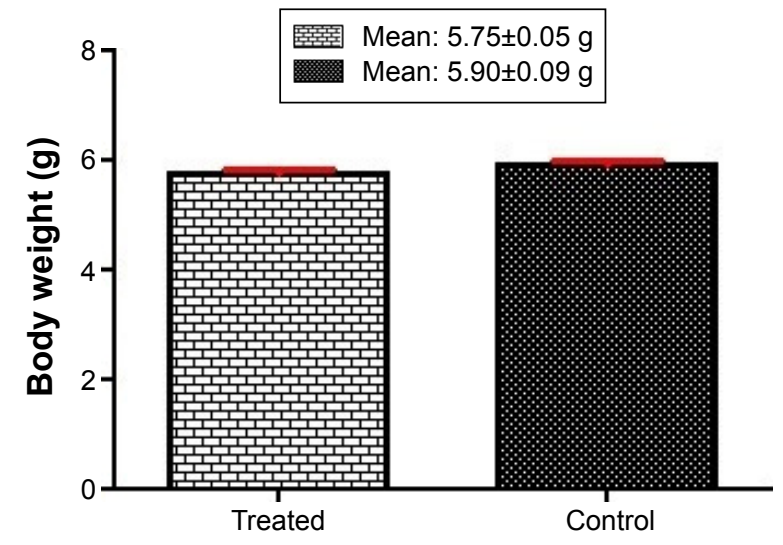

Figure I Body weight in studied groups.

Notes: Newborns' body weights were not different in fluoxetine treatment group (mean: $5.75 \pm 0.05 \mathrm{~g}$ ) and control group (mean: $5.90 \pm 0.09 \mathrm{~g}$ ).

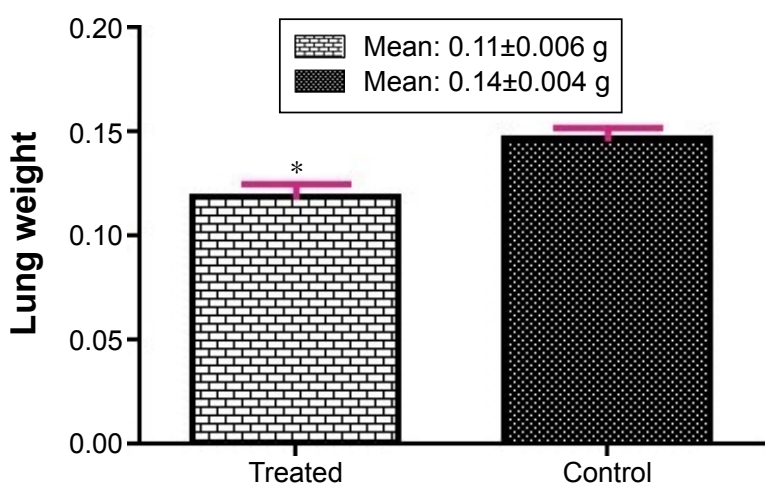

Figure 2 The lung weights.

Notes: Fluoxetine-exposed newborns' mean lung weights $(0.1 \mathrm{I} \pm 0.006 \mathrm{~g})$ compared with the control newborns' mean lung weights $(0.14 \pm 0.004 \mathrm{~g})$ were significantly reduced $(* P=0.001)$.

group was significantly increased compared with the control group $(P=0.0276)$ (Figure 4).

The mRNA of the SPC gene was expressed in type II alveolar cells. Although SPC was increased in the fluoxetine treatment group compared to the control group, this was nonsignificant $(P=0.1226)$ (Figure 5).

\section{Results of histological analyses}

Histology survey showed that the amount of mesenchymal tissue in the fluoxetine treatment group was more than in the control group which was elevated relative to the developmental time. The alveolar cells were formed in the control group and the walls between the alveolar cells were thinner than the fluoxetine treatment group (Figure 6).

\section{Discussion}

Therapeutic drugs is a path to overcome depression during pregnancy. Approximately $2 \%-3 \%$ of pregnant women

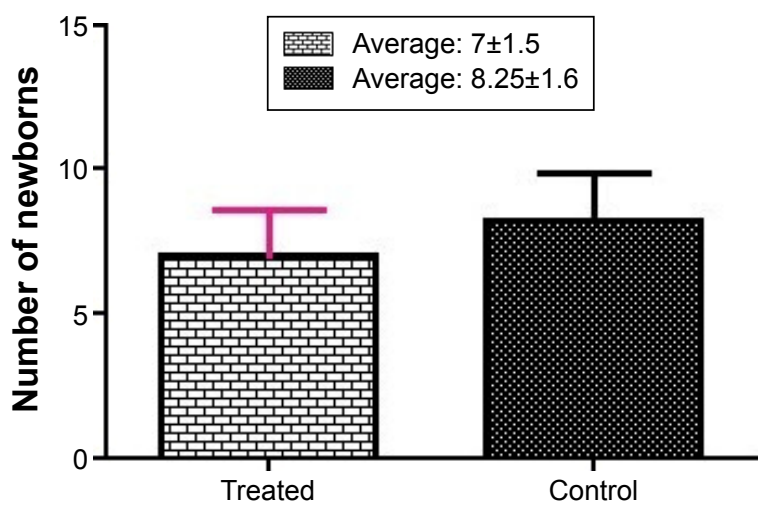

Figure 3 The number of newborns.

Notes: There was no statistically significant difference between average number

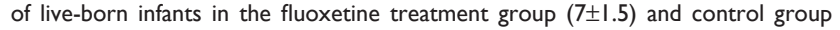
(8.25 \pm 1.6$)$. 


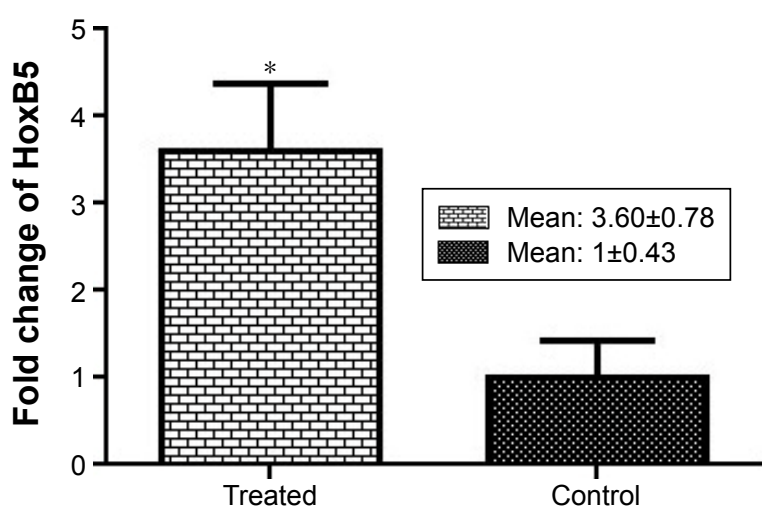

Figure 4 Fold changes of HoxB5 expression.

Note: The expression of HoxB5 in the fluoxetine treatment group compared with the control group showed a statistically significant increase $(* P=0.0276)$.

with depression receive SSRI drugs (such as fluoxetine). ${ }^{19}$ Fluoxetine increases the serotonin level, and an acute increase in serotonin in turn reduces uterine blood flow and leads to preterm birth and reduced fetal growth. ${ }^{3}$ The time of exposure to fluoxetine is important as Morrison et al demonstrated that first-trimester exposure to fluoxetine caused preterm birth, fetal growth restriction, and increased rates of miscarriage, ${ }^{3}$ while a fetus exposed to fluoxetine during the third trimester will require aspiratory support and hospitalization after birth. ${ }^{20}$

In the present study, the impact of maternal fluoxetine treatment was evaluated on the development of fetal rat lungs and the results showed the effect of fluoxetine on the fetal rat. In this study the number of live-born infants in the fluoxetine treatment group was lower than the control group, however it was nonsignificant, but the lung weights of fluoxetine-exposed newborns compared to the control newborns' lung weights were significantly reduced $(P<0.05)$. These weight changes and mortality were reported in other studies.

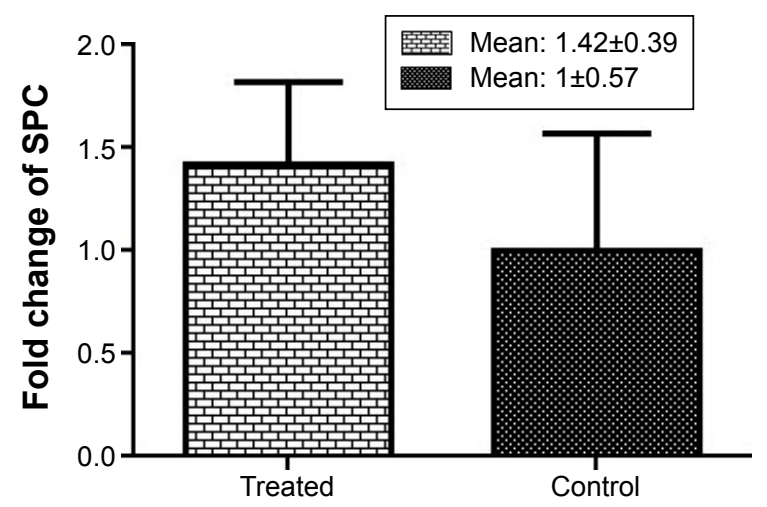

Figure 5 Fold changes of SPC expression.

Note: Expression of SPC in gene in the fluoxetine treatment group compared with control group showed an increase but this increase was nonsignificant $(P=0.1226)$.
Vorhees et al demonstrated that exposure to fluoxetine led to reduction of size in pregnant rats and increased mortality, although its mechanism is yet to be cleared. ${ }^{21}$ Morrison et al reported that the cause of this reduction in weight and the number of the newborns are due to the reduction of uterine blood flow after exposure to fluoxetine. ${ }^{22}$

The most important and novel result of this study is the effect of fluoxetine on expression of HoxB5 and $S P C$ genes.

Analysis of the real-time PCR showed the expression of both genes was increased and this increase was significant for the HoxB5 gene $(P=0.0276)$. HoxB5 is a homeobox-containing gene that plays an important role in the patterning of airway branches. ${ }^{11,23,24}$ Strong expression of this gene is found in lung mesenchyme during branching morphogenesis, and its expression falls in the saccular stage $^{11}$ and after birth it is expressed only in alveolar type I cells. Regarding, increased or decreased expression of this gene can serve as an indicator to show a problem in lung development. Overexpression of this gene could be indicative of a delay in lung development; however, a reduction in expression of this gene can imply a reduction in the number of alveolar type I cells. According to the histological analysis results of this study, it was found that lung development is delayed in the fluoxetine treatment group compared with the control group. With regard to the expected evolutionary time in this study, the mesenchymal tissue in the lungs of the fluoxetine treatment group is more than the control group and the lung tissue morphology is similar to pseudoglandular phase whereas, mesenchymal tissue has decreased in the control group and more alveolar cells have been established.

We observed in this study that the expression of SPC was increased, however this increase was not significant. Thus, according to the alveolar type II cells, cells differentiate into type I, and relative overexpression of the $S P C$ gene could be due to the lack of differentiation of alveolar type II cells toward type I and delay in development.

In 2007, Wang et al investigated the effect of alcohol on murine fetal lung and reported that alcohol delays the lung development and explained that the cause of overexpression of HoxB5 is delay in lung development. ${ }^{25}$

In $\mathrm{Xu}$ et al's study which evaluated the expression of HoxB5 and its role in neonatal rats with chronic lung disease, the cause of overexpression of $S P C$ is related to the lack of differentiation of alveolar type II cells toward type I. ${ }^{13}$

A number of studies also indicated the effects of fluoxetine on tissues and cells. 

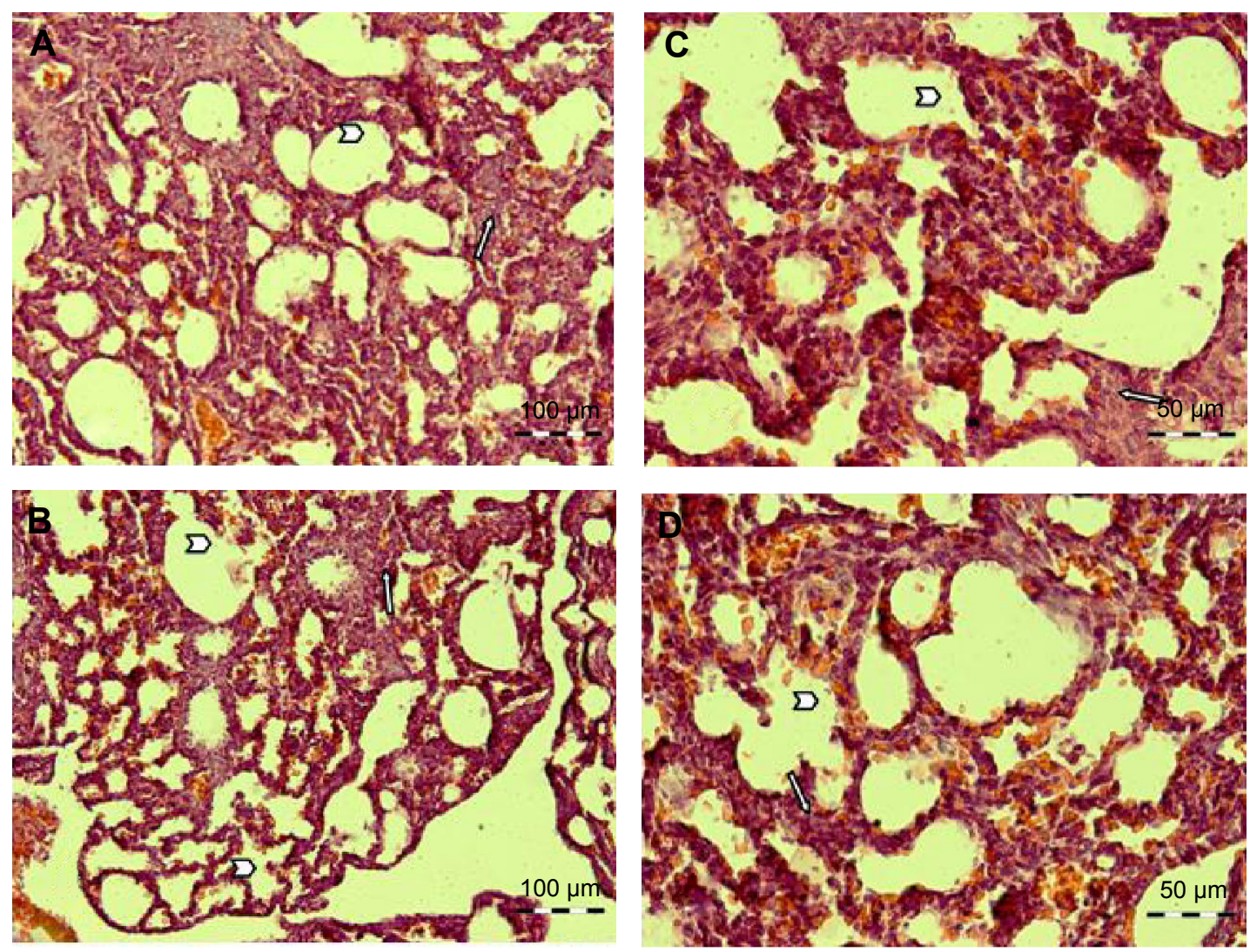

Figure 6 A representative picture of hematoxylin and eosin staining of rat lungs.

Notes: (A, B) Lung of the fluoxetine treatment group. The amount of mesenchymal tissue (arrow) is more than the control group. (C, D) Lung of the control group. The number of alveolar cells (arrowhead) are more than the fluoxetine treatment group and the walls between the alveolar cells are thin. Arrow: mesenchymal tissue. Arrowhead: alveolar cell. The magnification of $(\mathbf{A}, \mathbf{B}) \times 20$ (scale bar: $100 \mu \mathrm{m})$. The magnification of (C, D) $\times 40($ scale bar: $50 \mu \mathrm{m})$.

Swerts et al reported the effects of fluoxetine on nerve cells' development. They stated that the effect of fluoxetine on the elevated levels of serotonin led to the reduction in uterine blood flow which in turn can have an impact on the development of nerve cells. ${ }^{26}$

More recently in 2013, Kiryanova et al investigated the effects of fluoxetine on heart muscle cells and reported that exposure to fluoxetine during the neonatal period will lead to abnormality in cardiac growth and ventricular septal defects. ${ }^{27}$

Therefore, in agreement with aforementioned studies, our findings may also confirm fluoxetine's effects on development throughout fetal life. Some studies exist that suggest that SSRIs have an impact on pulmonary hypertension, ${ }^{5,28}$ and they have also reported that the highest concentration of fluoxetine accumulates within lungs after injection of fluoxetine in animals ${ }^{29,30}$ which can lead to PPHN. ${ }^{31}$ Even though the main cause of PPHN is not clear, one of the concerns could possibly be the increase in serotonin levels which results in increased pulmonary and smooth muscle cells' vasoconstriction. ${ }^{32}$

\section{Conclusion}

In the present study, we demonstrated that the exposure to fluoxetine during pregnancy caused increased expression of HoxB5 and $S P C$ in neonatal rats. The expression of the HoxB5 gene began at the earliest stages of lung development, peaked at the end of the pseudoglandular stage, and then its expression was moderated in the saccular stage.$^{33}$ Regarding histological analysis, it appears that the overexpression of this gene in the fluoxetine treatment group is probably due to the delay in lung development.

According to the other studies,, 528 one of the reasons for the delay in lung development can be the increase of serotonin levels in this tissue. On the other hand, pulmonary vascular and the bronchial tree development are equivalent. Therefore, maybe the effect of fluoxetine on vessels development ${ }^{9,34,35}$ can affect the development of the bronchial tree, although it's not clear.

Considering the results of the present study and other studies, it is important to be more scrutinizing before taking fluoxetine during pregnancy, so, it is essential to study the effects of antidepressant drugs during pregnancy. 


\section{Acknowledgment}

The authors of this article would like to thank Rafsanjan University of Medical Sciences as well as Dr Hasanshahi for editing the manuscript.

\section{Disclosure}

The authors report no conflicts of interest in this work.

\section{References}

1. Vivian-Taylor J, Hickey M. Menopause and depression: is there a link? Maturitas. 2014;79(2):142-146.

2. Kendall-Tackett K, Hale WT. The use of antidepressants in pregnant and breastfeeding women: a review of recent studies. J Hum Lact. 2010; 26(2):187-195.

3. Morrison JL, Riggs KW, Rurak DW. Fluoxetine during pregnancy: impact on fetal development. Reprod Fertil Dev. 2005;17(6):641-650.

4. Stark P, Fuller RW, Wong DT. The pharmacologic profile of fluoxetine. J Clin Psychiatry. 1985;46(3 Pt 2):7-13.

5. Kieler H, Artama M, Engeland A, et al. Selective serotonin reuptake inhibitors during pregnancy and risk of persistent pulmonary hypertension in the newborn: population based cohort study from the five Nordic countries. BMJ. 2012;344:d8012.

6. Porzionato A, Zaramella P, Macchi V, et al. Fluoxetine may worsen hyperoxia-induced lung damage in neonatal rats. Histol Histopathol. 2012;27(12):1599-1610.

7. Zhai FG, Zhang XH, Wang HL. Fluoxetine protects against monocrotaline-induced pulmonary arterial hypertension: potential roles of induction of apoptosis and upregulation of Kv1.5 channels in rats. Clin Exp Pharmacol Physiol. 2009;36(8):850-856.

8. Li XQ, Wang HM, Yang CG, Zhang XH, Han DD, Wang HL. Fluoxetine inhibited extracellular matrix of pulmonary artery and inflammation of lungs in monocrotaline-treated rats. Acta Pharmacol Sin. 2011;32(2):217-222.

9. Delaney C, Gien J, Grover TR, Roe G, Abman SH. Pulmonary vascular effects of serotonin and selective serotonin reuptake inhibitors in the late-gestation ovine fetus. Am J Physiol Lung Cell Mol Physiol. 2011; 301(6):L937-L944.

10. Golpon HA, Geraci MW, Moore MD, et al. HOX genes in human lung: altered expression in primary pulmonary hypertension and emphysema. Am J Pathol. 2001;158(3):955-966.

11. Volpe MV, Martin A, Vosatka RJ, Mazzoni CL, Nielsen HC. Hoxb-5 expression in the developing mouse lung suggests a role in branching morphogenesis and epithelial cell fate. Histochem Cell Biol. 1997; 108(6):495-504.

12. Rottier R, Tibboel D. Fetal lung and diaphragm development in congenital diaphragmatic hernia. Semin Perinatol. 2005;29(2):86-93.

13. Xu W, Yang N, Pan L, Fu J, Xue X. The expression of HoxB5 and its role in neonatal rats with chronic lung disease. Fetal Pediatr Pathol. 2012;31(1):11-20.

14. Brown NJ, Dohm MT, Bernardino de la Serna J, Barron AE. Biomimetic $\mathrm{N}$-terminal alkylation of peptoid analogues of surfactant protein $\mathrm{C}$. Biophys J. 2011;101(5):1076-1085.

15. Mulugeta S, Maguire JA, Newitt JL, Russo SJ, Kotorashvili A, Beers MF. Misfolded BRICHOS SP-C mutant proteins induce apoptosis via caspase-4- and cytochrome c-related mechanisms. Am J Physiol Lung Cell Mol Physiol. 2007;293(3):L720-L729.

16. Muller JC, Boareto AC, Lourenco EL, et al. In utero and lactation exposure to fluoxetine in Wistar rats: pregnancy outcomes and sexual development. Basic Clin Pharmacol Toxicol. 2013;113(2):132-140.
17. Liu X, Smith BJ, Chen C, et al. Use of a physiologically based pharmacokinetic model to study the time to reach brain equilibrium: an experimental analysis of the role of blood-brain barrier permeability, plasma protein binding, and brain tissue binding. J Pharmacol Exp Ther. 2005;313(3):1254-1262.

18. Schmittgen TD, Livak KJ. Analyzing real-time PCR data by the comparative C(T) method. Nat Protoc. 2008;3(6):1101-1108.

19. ACOG Committee on Obstetric Practice. Committee Opinion No. 354 : Treatment with selective serotonin reuptake inhibitors during pregnancy. Obstet Gynecol. 2006;108(6):1601-1603.

20. drugs.com [homepage on the Internet]. Fluoxetine. Available from: https://www.drugs.com/pro/Fluoxetine.html. Accessed July 13, 2016.

21. Vorhees CV, Acuff-Smith KD, Schilling MA, Fisher JE, Moran MS, Buelke-Sam J. A developmental neurotoxicity evaluation of the effects of prenatal exposure to fluoxetine in rats. Fundam Appl Toxicol. 1994; 23(2):194-205.

22. Morrison JL, Chien C, Riggs KW, Gruber N, Rurak D. Effect of maternal fluoxetine administration on uterine blood flow, fetal blood gas status, and growth. Pediatr Res. 2002;51(4):433-442.

23. Chinoy MR, Volpe MV, Cilley RE, et al. Growth factors and dexamethasone regulate Hoxb5 protein in cultured murine fetal lungs. $\mathrm{Am}$ J Physiol. 1998;274(4 Pt 1):L610-L620.

24. Volpe MV, Archavachotikul K, Bhan I, Lessin MS, Nielsen HC. Association of bronchopulmonary sequestration with expression of the homeobox protein Hoxb-5. J Pediatr Surg. 2000;35(12):1817-1819.

25. Wang X, Gomutputra P, Wolgemuth DJ, Baxi L. Effects of acute alcohol intoxication in the second trimester of pregnancy on development of the murine fetal lung. Am J Obstet Gynecol. 2007;197(3): 269.e1-e4.

26. Swerts CA, Costa AM, Esteves A, Borato CE, Swerts MS. Effects of fluoxetine and imipramine in rat fetuses treated during a critical gestational period: a macro and microscopic study. Rev Bras Psiquiatr. 2010;32(2):152-158.

27. Kiryanova V, McAllister BB, Dyck RH. Long-term outcomes of developmental exposure to fluoxetine: a review of the animal literature. Dev Neurosci. 2013;35(6):437-449.

28. Reeve HL, Nelson DP, Archer SL, Weir EK. Effects of fluoxetine, phentermine, and venlafaxine on pulmonary arterial pressure and electrophysiology. Am J Physiology. 1999;276(2 Pt 1):L213-L219.

29. Pohland RC, Byrd TK, Hamilton M, Koons JR. Placental transfer and fetal distribution of fluoxetine in the rat. Toxicol Appl Pharmacol. 1989; 98(2): 198-205.

30. Shiue CY, Shiue GG, Cornish KG, O'Rourke MF. PET study of the distribution of [11C]fluoxetine in a monkey brain. Nucl Med Biol. 1995; 22(5):613-616

31. Chambers CD, Hernandez-Diaz S, Van Marter LJ, et al. Selective serotonin-reuptake inhibitors and risk of persistent pulmonary hypertension of the newborn. $N$ Eng J Med. 2006;354(6):579-587.

32. Eddahibi S, Guignabert C, Barlier-Mur AM, et al. Cross talk between endothelial and smooth muscle cells in pulmonary hypertension: critical role for serotonin-induced smooth muscle hyperplasia. Circulation. 2006;113(15):1857-1864

33. Volpe MV, Ramadurai SM, Mujahid S, et al. Regulatory interactions between androgens, Hoxb5, and TGF $\beta$ signaling in murine lung development. Biomed Res Int. 2013;2013:320249.

34. Ornoy A, Koren G. Selective serotonin reuptake inhibitors in human pregnancy: on the way to resolving the controversy. Semin Fetal Neonatal Med. 2014;19(3):188-194.

35. Fornaro E, Li D, Pan J, Belik J. Prenatal exposure to fluoxetine induces fetal pulmonary hypertension in the rat. Am J Respir Crit Care Med. 2007;176(10):1035-1040 


\section{Publish your work in this journal}

Drug Design, Development and Therapy is an international, peerreviewed open-access journal that spans the spectrum of drug design and development through to clinical applications. Clinical outcomes, patient safety, and programs for the development and effective, safe, and sustained use of medicines are the features of the journal, which has also been accepted for indexing on PubMed Central. The manuscript management system is completely online and includes a very quick and fair peer-review system, which is all easy to use. Visit http://www.dovepress.com/testimonials.php to read real quotes from published authors.

Submit your manuscript here: http://www.dovepress.com/drug-design-development-and-therapy-journal 